\title{
Correction to: Biodiesel production from microalgae Dunaliella tertiolecta: a study on economic feasibility on large-scale cultivation systems
}

\author{
Akash Patel $^{1,2} \cdot$ Bharat Gami $^{1} \cdot$ Pankaj Patel $^{1} \cdot$ Beena Patel $^{1,2}$ (D) \\ Published online: 25 January 2021 \\ (C) Springer-Verlag GmbH Germany, part of Springer Nature 2021
}

\section{Correction to: Biomass Conversion and Biorefinery} https://doi.org/10.1007/s13399-020-01191-1

The original version of this article unfortunately contained a mistake. One of the affiliations was incorrect. The correct information is given below.

The original article has been corrected.

Publisher's Note Springer Nature remains neutral with regard to jurisdictional claims in published maps and institutional affiliations.

The online version of the original article can be found at https://oi.org/ 10.1007/s13399-020-01191-1

Beena Patel

beena.p@abellon.com; https://www.abellon.com

1 Abellon Cleanenergy Limited, Sangeeta Complex, Nr. Parimal Crossing, Ellisbridge, Ahmedabad, Gujarat 380006, India

2 Department of Biotechnology, Hemchandracharya North Gujarat University, Patan, Gujarat 384265, India 